\title{
DiscoverArchive
}

Retrieved from DiscoverArchive,

Vanderbilt University's Institutional Repository

Published as Nancy J. King, Non-Capital Habeas Cases after Appellate Review: An

Empirical Analysis in 24 Fed. Sent. R. 208 2012. (C) 2012 by the Regents of the

University of California. Copying and permissions notice: Authorization to copy this content beyond fair use (as specified in Sections 107 and 108 of the U. S. Copyright Law) for internal or personal use, or the internal or personal use of specific clients, is granted by the Regents of the University of California for libraries and other users, provided that they are registered with and pay the specified fee via Rightslink ${ }^{\circledR}$ on JSTOR (http://www.jstor.org/r/ucal) or directly with the Copyright Clearance Center, http://www.copyright.com. 
Non-Capital Habeas Cases after Appellate Review: An Empirical Analysis

Author(s): Nancy J. King

Reviewed work(s):

Source: Federal Sentencing Reporter, Vol. 24, No. 4, Prisoner Rights and Habeas Corpus:

Assessing the Impact of the 1996 Reforms (April 2012), pp. 308-320

Published by: University of California Press on behalf of the Vera Institute of Justice

Stable URL: http://www.jstor.org/stable/10.1525/fsr.2012.24.4.308

Accessed: 09/01/2013 15:02

Your use of the JSTOR archive indicates your acceptance of the Terms \& Conditions of Use, available at http://www.jstor.org/page/info/about/policies/terms.jsp

JSTOR is a not-for-profit service that helps scholars, researchers, and students discover, use, and build upon a wide range of content in a trusted digital archive. We use information technology and tools to increase productivity and facilitate new forms of scholarship. For more information about JSTOR, please contact support@jstor.org. 


\section{Non-Capital Habeas Cases after Appellate Review: An Empirical Analysis}

In 2007, a decade after AEDPA's effective date, the first empirical study of litigation under the Act was released. In the study, a team of researchers from the National Center for State Courts and I examined district court activity in 2384 randomly selected, non-capital habeas cases, approximately 6.5 percent of the non-capital habeas cases commenced in federal district courts in 2003 and 2004 by state prisoners. ${ }^{2}$ In this article, I follow those same cases into the courts of appeals. ${ }^{3}$ Part A summarizes appellate activity overall. Part B examines in more detail the cases from the study in which petitioners received relief.

\section{A. Summary of Appellate Activity}

The 2384 district court cases in the 2007 study sample produced more than 896 cases filed in the courts of appeals. This level of appellate activity-roughly three appellate cases for every eight district court cases filedmirrors the volume reported by the Administrative Office of the Courts. Each year, the federal courts consider more than $\mathrm{I} 6,000$ non-capital state prisoner habeas cases at the trial level, and more than 6200 such cases in the courts of appeals, nearly half of which are filed in just two circuits: the Fifth and the Ninth. ${ }^{4}$

For each of the 2188 terminated district court cases in the 2007 study sample, 5 this article tracks two categories of court of appeals cases: First, any appeal of the initial district court judgment, and, second, if the district court dismissed the petition as successive and a separate appeal of that dismissal was not filed, any immediate request for authorization from the court of appeals to file a successive petition. Information about the following filings in the courts of appeals was not collected: (I) any interlocutory appeal of a district court order before final judgment; (2) any appeal consolidated together with another appellate case; (3) any request for permission to file a successive petition filed by a petitioner who also filed a separate appeal of the district court's dismissal; and (4) any later appeal of a new district court judgment after remand. Because these filings (many of which were assigned separate case numbers in the courts of appeals) are excluded from the volume of appellate activity reported here, that volume probably underestimates the actual amount of habeas litigation in the courts of appeals. ${ }^{6}$ This methodology identified appellate activity for approximately 4I percent of the study cases that had terminated in the district courts. A summary of the appellate activity generated by these cases appears in Table I.

\section{Appeals by the state}

By December 20II, only I2 of the 2384 study cases were still pending in the district courts, and petitioners had received some sort of favorable decision from the district courts in a total of fourteen cases.7 See Table 2. States' attorneys appealed the district court's decision to grant the writ in six of those fourteen cases, an appeal rate of 42 percent. In two of those six appeals the district court's decision was vacated, a I-in-3 win rate on appeal.

\section{Appeals by petitioners}

Although petitioners in the study sample chose to appeal their adverse judgments almost as often as states-about 38 percent of the time overall ${ }^{8}$ - they fared much worse in the courts of appeals. Fewer than 2 in Ioo obtained any sort of remand. 9

a. Certificates of appealability. Most petitioners, 77 percent, lost their appeals when the courts of appeals denied their requests for certificates of appealability (COAs). Under $\ 2253$, a petitioner must first obtain a COA from either the district court or the court of appeals before the court of appeals will consider his appeal. ${ }^{\text {to }}$ The COA defines the issues subject to review, and is available only upon a "substantial showing of the denial of a constitutional right." "I This has proven to be a formidable barrier to review. In fewer than half of the cases ending in denial or dismissal in the district courts ${ }^{\mathrm{I} 2}$ did the petitioner receive a COA ruling from either court. More than 92 percent of all COA rulings were denials. See Table 3.

Rulings on COAs varied greatly between circuits. Consider the two circuits with the largest volume of habeas cases, for example. In the Ninth Circuit, district judges granted more than I4 percent and the court of appeals granted more than $\mathrm{I} 3$ percent of COAs sought, while in the Fifth Circuit, every COA sought from a district judge was denied, and only 7 percent were granted by the court of appeals.

Federal Sentencing Reporter, Vol. 24, No. 4, pp. 308-319, ISSN 1053-9867 electronic ISSN 1533-8363. (C) 2012 Vera Institute of Justice. All rights reserved. Please direct requests for permission to photocopy or reproduce article content through the University of California Press's Rights and Permissions website, http://www.ucpressjournals.com/reprintInfo.asp. DOI: I0.I525/fsr.20I2.24.4.308. 
Table 1.

Summary of Appellate Activity

\begin{tabular}{|c|c|c|c|c|c|c|}
\hline \multirow[b]{2}{*}{ Circuit } & \multirow[b]{2}{*}{$\begin{array}{c}\text { Total Cases Filed } \\
\text { in District Courts } \\
\text { within Circuit }\end{array}$} & \multicolumn{2}{|c|}{ No Appellate Activity } & \multicolumn{3}{|c|}{ Appellate Activity } \\
\hline & & $\begin{array}{l}\text { Percentage of } \\
\text { cases with no } \\
\text { appeals activity* }\end{array}$ & $\begin{array}{c}\text { Number of } \\
\text { cases with no } \\
\text { appeals activity }\end{array}$ & $\begin{array}{l}\text { Number of } \\
\text { cases petitioner } \\
\text { filed appeal }\end{array}$ & $\begin{array}{l}\text { Number of cases fol- } \\
\text { lowed by request to } \\
\text { file successive petition }\end{array}$ & $\begin{array}{l}\text { Number of cases } \\
\text { in which state } \\
\text { filed appeal }\end{array}$ \\
\hline I & 27 & $67 \%$ & I8 & 8 & I & $\circ$ \\
\hline 2 & I75 & $58 \%$ & IOI & 70 & 3 & I \\
\hline 3 & I49 & $60 \%$ & 90 & 56 & 2 & I \\
\hline 4 & I83 & $59 \%$ & 107 & 75 & I & $\circ$ \\
\hline 5 & 463 & $67 \%$ & 310 & I34 & I9 & $\circ$ \\
\hline 6 & I93 & $63 \%$ & $\mathrm{I} 22$ & 62 & 9 & o \\
\hline 7 & 169 & $72 \%$ & I2I & 46 & 2 & $\circ$ \\
\hline 8 & II5 & $67 \%$ & 77 & $3 \mathrm{I}$ & 7 & $\circ$ \\
\hline 9 & $5^{\text {II }}$ & $57 \%$ & 292 & 202 & I4 & 3 \\
\hline IO & 89 & $55 \%$ & 49 & 33 & 7 & $\circ$ \\
\hline II & 310 & $65 \%$ & 200 & IOI & 8 & I \\
\hline Totals & 2384 & $62 \%$ & I488 & $8 \mathrm{I} 7$ & 73 & 6 \\
\hline
\end{tabular}

*Of all cases filed in districts within each circuit, including cases still pending in the district court and those transferred to another district. Of total cases terminated in the district courts in favor of the state, about $38 \%$ were appealed by petitioners. See note 8 and accompanying text.

\section{b. Other reasons petitioners secured no relief on}

appeal. Even with a COA, petitioners were likely to lose in the courts of appeals. Petitioners secured no relief in all three of the study cases in which both the circuit and the district court granted a COA, forty-four of the forty-nine cases appealed after the district judge granted a COA, ${ }^{13}$ and thirty-eight of the fifty cases in which the court of appeals granted a COA.

In addition to the appeals that ended when a COA was denied, and those that failed after a COA grant, another I2 percent of petitioners' attempts to appeal were rejected for a variety of reasons including untimeliness, failure to pay fees, and voluntary dismissal. ${ }^{\mathrm{I}}$

\section{Requests for permission to file successive petitions}

AEDPA bars a district judge from considering a successive petition unless the petitioner first obtains permission to file that petition from the court of appeals. Permission to file a successive petition with a new claim will be granted only if the petitioner demonstrates that his new claim either (I) relies on a new constitutional rule that the Supreme Court has made retroactively applicable, or (2) is based on newly discovered facts that, together with other evidence, convincingly demonstrate his innocence of the underlying offense. ${ }^{\text {I5 }}$ Although some petitioners seek such permission before attempting to file a successive petition in district court, others seek such permission only after the district court has rejected a petition as successive. Because a request for permission filed in the court of appeals after a district judge's dismissal functions somewhat like an appeal, these requests were also tracked.

Such requests reach the courts of appeals in one of two ways. When rejecting a petition as successive, some district judges routinely "transfer" the case to the court of appeals, where a new case-usually captioned In re [petitioner's last name] - is then opened. The transfer order from the district court is docketed as part of that new case,

Table 2.

Summary of Outcomes in Federal Court

\begin{tabular}{|c|c|c|c|c|c|}
\hline \multicolumn{6}{|l|}{ Cases Completed* I००\% (2I88) } \\
\hline District Ct Cases Denying Relief & $99.4 \%$ & $2 \mathrm{I} 74$ & District Ct Cases Granting Relief & $0.6 \%$ & I4 \\
\hline COA granted by any court & $4.7 \%$ & IO3 & Appealed by State & $0.3 \%$ & 6 \\
\hline Remanded to district court & $0.7 \%$ & I6 & Reversed & $0.01 \%$ & 2 \\
\hline New grants after remand ${ }^{k *}$ & $0.28 \%$ & 6 & Grants Remaining After Appeal & $0.55 \%$ & $\mathrm{I} 2$ \\
\hline
\end{tabular}

*Does not include cases transferred to another district or the I2 cases still pending in the District Court

${ }^{* *}$ Does not include one case still pending on remand in the District Court 
Table 3.

Rulings on Certificates of Appealability by Circuit

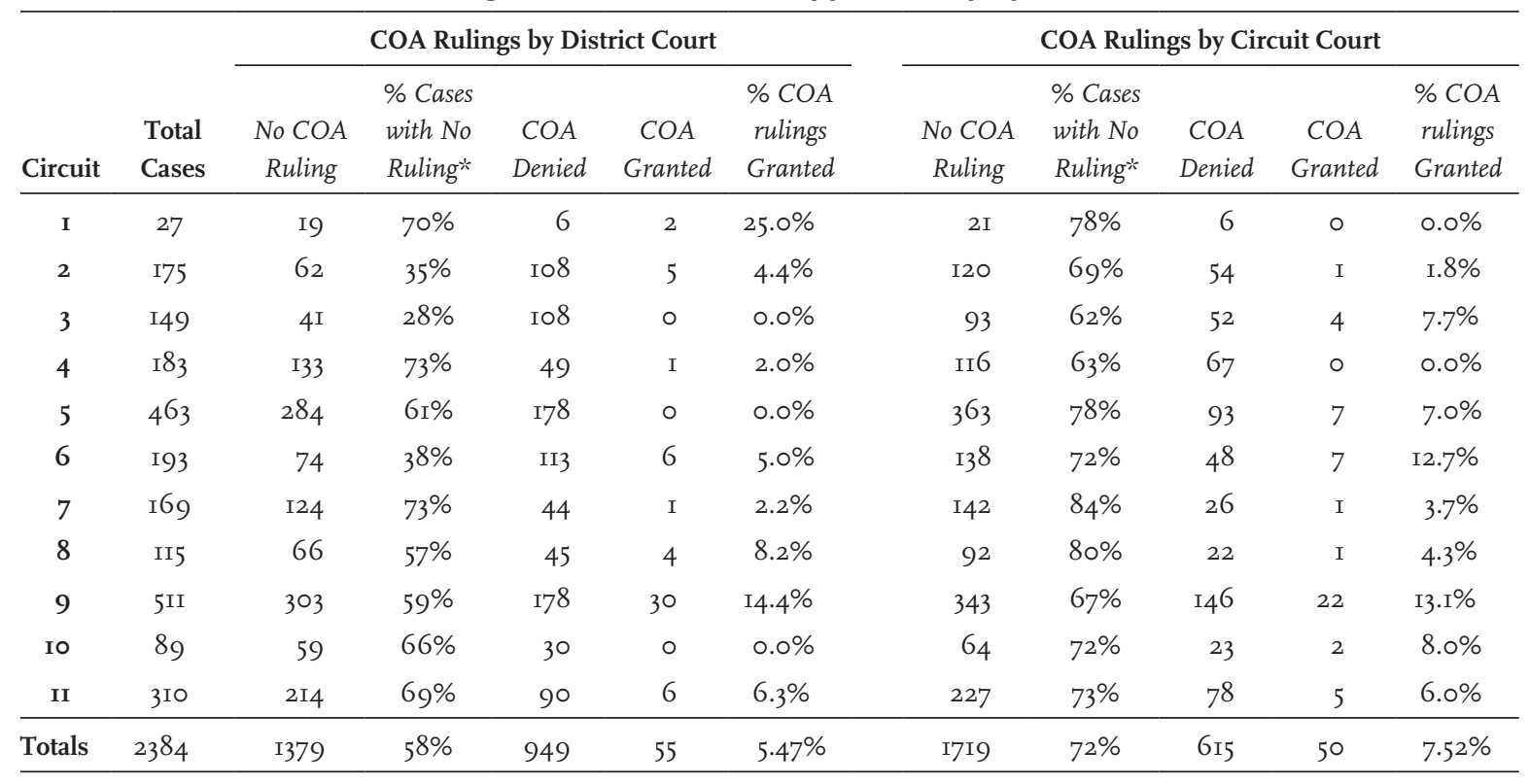

* Of all cases filed in district courts in each circuit, including cases still pending in the district court and those transferred to another district. For percentages calculated using only cases terminated in the district courts in favor of the state, see text at notes Io-I2, and note I9.

where it essentially serves as the petitioner's request for the court of appeals to rule one way or the other on whether he will be allowed to file a successive petition. Other district judges simply dismiss successive petitions, leaving it to the petitioner to file in the court of appeals a request for permission to file a successive petition.

Of the petitioners in the study whose petitions were rejected by the district court as successive, more than half proceeded to the court of appeals with an appeal or, more often, a request in the court of appeals for permission to file a successive petition. ${ }^{16}$ Not one succeeded; all requests were denied. ${ }^{\text {T7}}$

\section{B. Grants of Relief}

The 2007 study reported a very low grant rate in the district courts-by the end of 2006 , less than 0.4 percent of non-capital habeas petitioners whose cases had concluded in the district courts had succeeded in securing a grant of relief from a district judge. As the report observed, without examining how many additional petitioners received relief after review by the courts of appeals, it was not possible to report an overall grant rate. ${ }^{\mathrm{I} 8}$

Now that almost all of the study cases have wound their way through the appellate system, a preliminary estimate of the overall grant rate is possible. Examining the study cases at the end of 2oII reveals that for state prisoners serving non-capital sentences the chance of habeas relief, even when appellate review is taken into account, remains remote. The percentage of these petitioners receiving any sort of relief in federal court seven or eight years after filing, considering both district and circuit court review, is just 0.8 percent. This remains less than the grant rate reported in district courts alone in cases litigated prior to AEDPA. ${ }^{19}$

Specifically, as of December 20II, among the 2I 88 study cases that had terminated in the district courts, ${ }^{20} \mathrm{a}$ total of eighteen petitioners received any favorable ruling. Of these, twelve were district court judgments granting the writ that were either affirmed on appeal or not appealed, and six were cases in which petitioners received relief after successfully appealing a district court judgment that had denied or dismissed the petition. See Table 2.

The eighteen cases in which state prisoners in the study sample received some sort of relief from federal litigation are detailed in Table 4. The table collects the following information for each case: district (state), conviction(s) underlying custody, sentence(s) imposed, date sentence(s) imposed, count that was at issue in habeas case, error found by the federal court, proceeding in which error occurred, county of prosecution, whether an evidentiary hearing was held on the claim in federal or in state court, whether the deferential standard of $\int 2254$ (d) was applied, type of relief ordered, date relief ordered, and the outcome in state court after federal habeas review terminated.

\section{Errors underlying relief; relief ordered}

It is difficult to find any sort of pattern in these casesthey appear to be a random assortment of errors affecting a wide variety of proceedings.

a. Cases challenging decisions other than state criminal judgment. A surprisingly large proportion of non-capital habeas cases filed by state prisoners challenge not the 


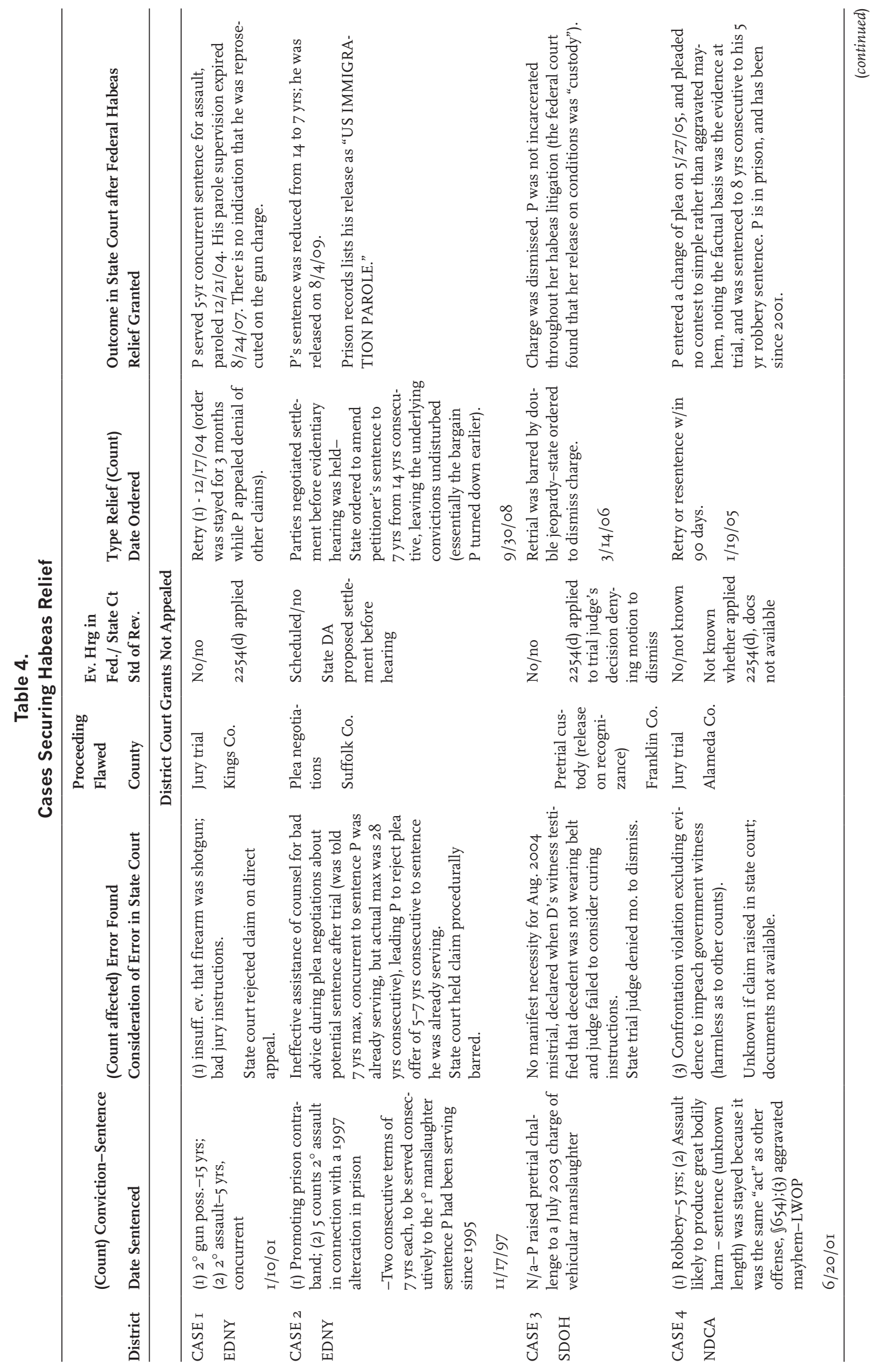

FEDERAL SENTENCING REPORTER • VOL. 24, NO. 4 • APRIL 2012 


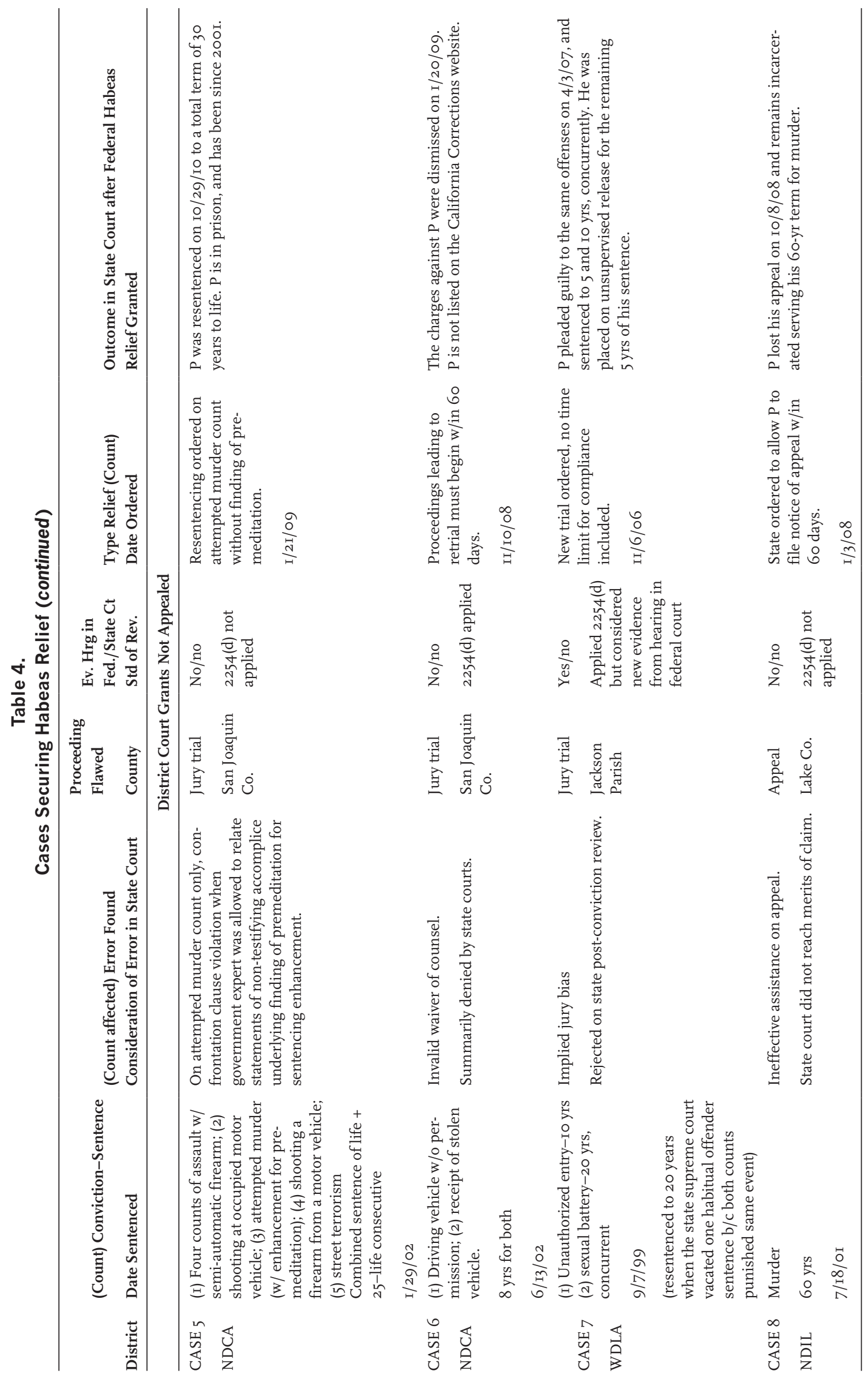




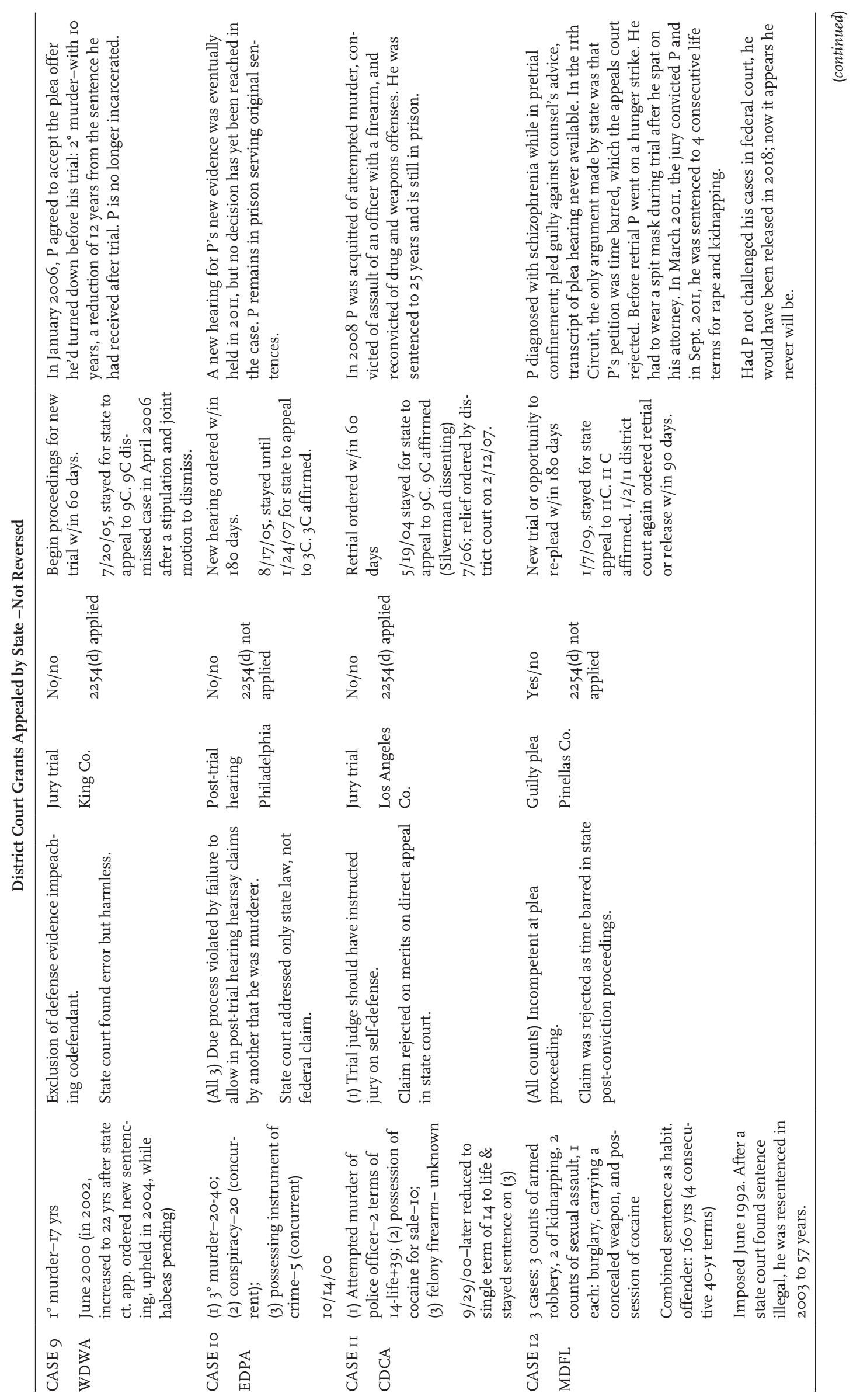

FEDERAL SENTENCING REPORTER • VOL. 24, NO. 4 • APRIL 2012 


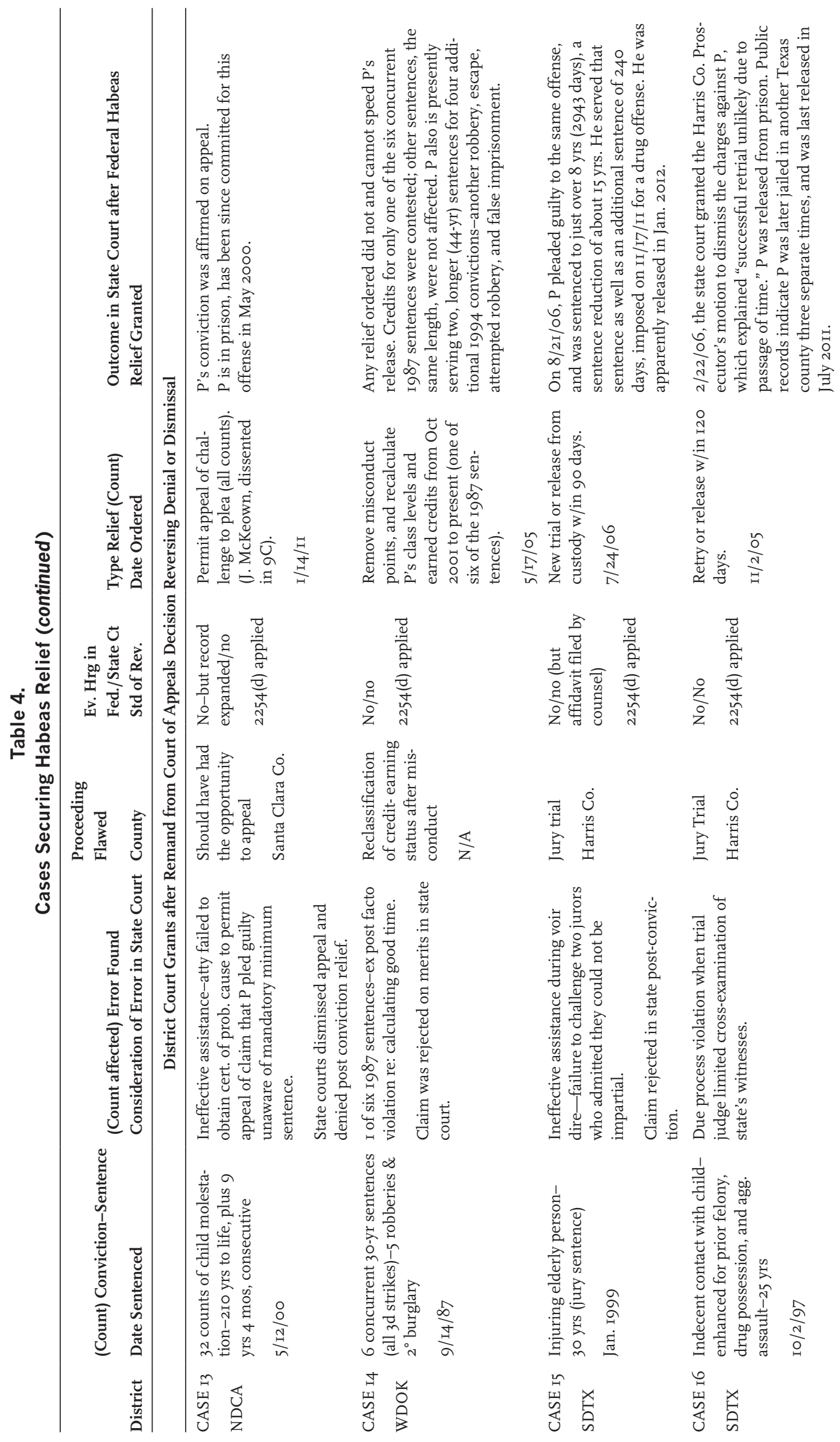



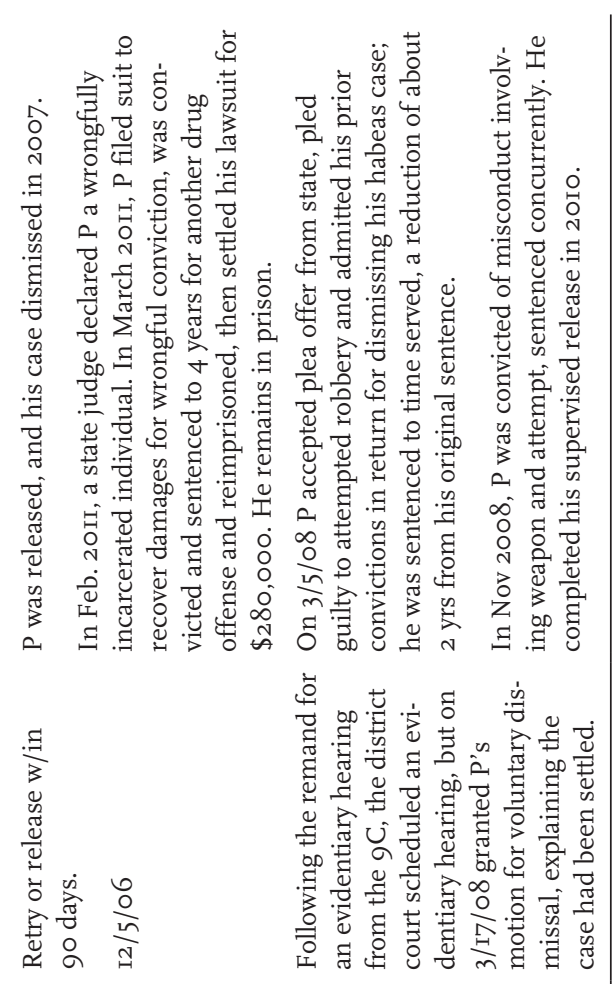

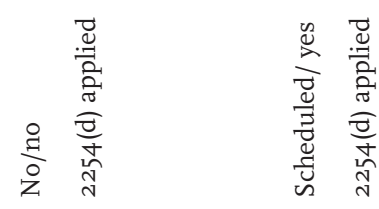

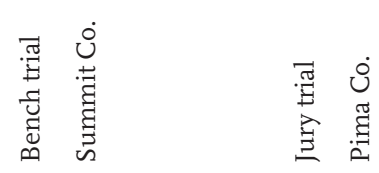

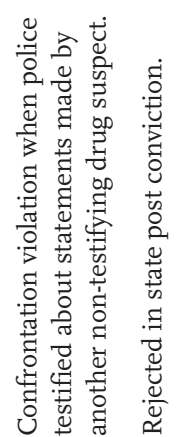
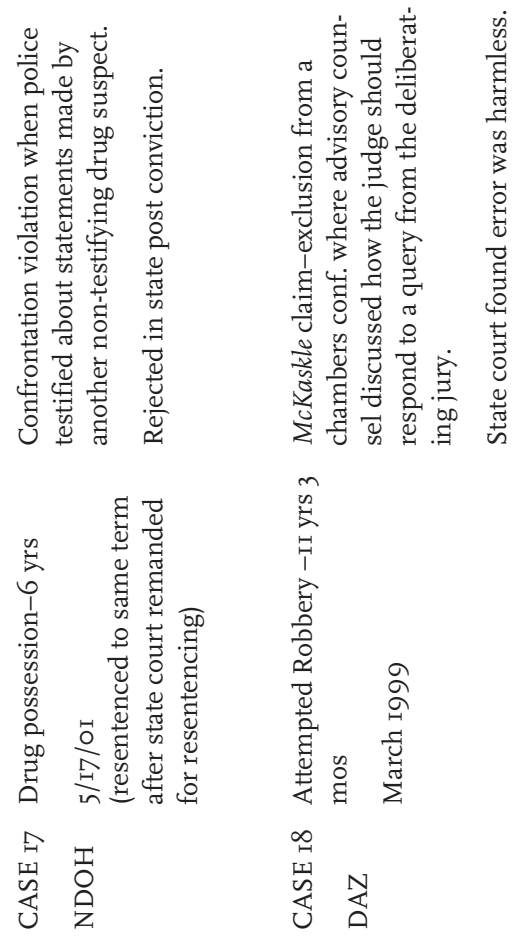

validity of a conviction or sentence, but instead a separate state decision affecting custody, often a decision denying or revoking release on parole or a decision to revoke or limit good-time credits after a finding of misconduct. ${ }^{2 \mathrm{I}}$ Two of these cases from the study were among the eighteen cases in which relief was granted.

In Case 3 the petitioner, awaiting retrial after her first trial for vehicular homicide ended in mistrial, claimed that her prosecution violated the Double Jeopardy Clause. The district court found unreasonable the state trial court's decision that there was manifest necessity for the mistrial and barred the state from continuing the prosecution.

The other case of this type, Case I4, concerned a challenge to a state's calculation of the petitioner's good time after a finding of prison misconduct. The district court initially granted the writ concluding that the state violated the petitioner's rights under the Ex Post Facto Clause by determining his eligibility to earn credits using a rule that had been adopted after his misconduct had taken place. Over a year later, when the state sought reconsideration of that ruling under Rule 59, the district court vacated its grant and denied the petition, recognizing that there had been no increase in punishment beyond what petitioner faced on the date of the underlying offense. The Tenth Circuit ordered the grant reinstated, not because the district court had erred on the merits, but because it had vacated its judgment after the period for reconsideration under Rule 59 had expired.

b. Cases challenging conviction or sentence. In the other sixteen cases ending in relief for the petitioner, the petitioner challenged the constitutionality of his conviction or sentence and the federal court ordered some sort of do-over in state court: a retrial, resentencing, new posttrial hearing, or new appeal.

Counsel-related errors were the basis for relief in six cases: two cases of ineffective assistance of counsel on appeal; one each with ineffectiveness during voir dire or plea negotiations; a violation of the right to proceed without counsel; and an invalid waiver of counsel.

The cases in which petitioners secured relief from the federal courts also included multiple violations of rights protecting the defendant's ability to test the accuracy of the state's case, including the right to present defense evidence and to impeach or confront prosecution witnesses. Six cases presented this sort of claim. Flaws in the remaining cases included insufficient evidence of an element at trial, jury bias, and faulty jury instructions. ${ }^{22}$ Interestingly, all but one of the sixteen orders granting relief from a criminal judgment involved an error that affected the validity of the conviction, not a sentencing error. Also, in more than half of these sixteen cases, the constitutional error occurred at a jury trial.

2. Representation of winning petitioners in habeas Petitioners who won relief were more likely than other non-capital habeas petitioners to have lawyers helping 
them. Compared to the estimated 7 to 8 percent of all non-capital habeas petitioners represented by counsel, ${ }^{23}$ 67 percent (eight of twelve) of the petitioners who succeeded in the district courts had attorneys. ${ }^{24}$ Similarly, four of the six petitioners who received relief after appealing the denial or dismissal of their petitions had counsel in the court of appeals. ${ }^{25}$

\section{Remands not producing relief}

In addition to the cases detailed in Table 4, in nine other cases the circuit court sent the case back to the district court for additional proceedings that resulted in no relief for the petitioner. In all but two of these cases, the court of appeals found fault not with the district judge's assessment of the merits of a constitutional claim, but instead with the resolution of some aspect of habeas procedure apart from the merits.

Specifically, one case was remanded because there was an "incomplete record"; one involved the application of the rules of exhaustion; two involved questions about tolling of the statute of limitations period; two concerned procedural default; and one concerned whether or not petitioner had been diligent in trying to develop the factual basis of his claim in state court. The remand orders in these cases all directed the district court to apply the appropriate procedural rules. In two additional cases, the court of appeals found that the district court should have reached the merits of a claim: the Ninth Circuit vacated the summary dismissal of a petitioner's claim that delay in state post-conviction proceedings can itself violate due process, citing Ninth Circuit precedent, and the Sixth Circuit ordered the district court to consider, after the Supreme Court's new decision in Blakely, an argument for relief that was later rejected by the Court in Oregon v. Ice. After being remanded, each of these cases was resolved in favor of the state. ${ }^{26} \mathrm{~A}$ tenth case was remanded by the Second Circuit for consideration of whether an Apprendi claim in an amended petition "relates back," and that case remains pending in district court.

\section{The rest of the story-after relief ordered}

What happened to the eighteen petitioners who won their federal habeas cases? In four of the eighteen cases, the petitioner's habeas victory landed him in a position that was the same as or worse than the position he was in before he sought habeas relief. The petitioner in Case I2 successfully upended a combined fifty-seven-year sentence for multiple rapes, robberies, and kidnappings-a sentence that he would have finished in 2018 - only to be retried, reconvicted, and sentenced to four consecutive life terms. The prisoner who won his ex post facto challenge in Case I4 had his good-time credits recalculated for one of his I987 sentences, but his release date was unaffected because he is serving multiple additional sentences of equal or greater length imposed in either 1987 or 1994 . Two others (Cases 8 and Io) each lost the direct appeal that the federal judge ordered the state to provide.
At the other end of the spectrum, in four cases it appears that as a result of the federal litigation, the challenged charge against the petitioner was dismissed and the petitioner released. The double jeopardy case discussed above (Case 3 ) is one of these cases. A second case (Case I7) involved what courts later found to be a wrongful drug conviction. After the federal court ordered retrial because of a confrontation violation, the petitioner was released. (Just days before settling his lawsuit to recover damages for his wrongful conviction, he was sent to prison for a subsequent drug offense.) In a third case of release, Case $\mathrm{I} 6$, after the district court rejected petitioner's claims that he was actually innocent of the offense of indecent contact with a child, and that restrictions on cross-examination violated his rights to confrontation and due process, the Fifth Circuit granted a COA on these two issues as well as whether petitioner had defaulted several claims. It then ordered retrial, concluding that the case "turned entirely on the credibility of the complaining [child] witness," and that "the state courts' restriction on [the petitioner's] ability to challenge that credibility violated his clearly-established confrontation and due process rights and cannot be considered harmless." The state chose not to retry him and he was released-nine years after his conviction. In a fourth case, Case 6 , the federal court found in 2008 that the petitioner, sentenced in 2002 to two concurrent terms of eight years, subject to parole, had not validly waived his right to counsel. The charges were dropped in 2009 , the year before his sentence would have expired.

Of the eleven remaining grants of relief:

- Two petitioners were convicted and sentenced in state court for a lesser offense after successfully challenging a conviction. The petitioner in Case II, whose attempted murder conviction was found flawed because the trial judge refused to instruct the jury on self-defense, was convicted of aggravated assault instead and is now serving a twenty-five-year sentence on that offense combined with other undisturbed counts of conviction, instead of his original term of fourteen to life. In Case 9, the petitioner settled while the state's appeal was pending in the $9^{\text {th }}$ Circuit, agreeing that in return for vacating his firstdegree murder conviction and sentence of twenty-two years, he would plead guilty to seconddegree murder with a ten-year term, the same deal he had turned down before trial.

- In two cases, Cases I and 4, one of several convictions was vacated, and the petitioner served or is serving lesser sentences on the other counts.

- Five cases received a lower sentence after reconviction or resentencing for the same offense: The petitioner in Case 2 negotiated a reduction in sentence from fourteen to seven years. The petitioner in Case 5 was resentenced to a single life term rather than two consecutive life terms for his attempted murder and additional crimes. The petitioner in 
Case 7 pleaded guilty to the same offenses, but with a ten-year term rather than the earlier twentyyear term. The petitioner in Case I5 pleaded guilty to the same offense, but secured a sentence about fifteen years less than his initial sentence. The petitioner in Case I8 dismissed his habeas case on remand in return for a sentence reduction of about two years.

- Finally, one case is unfinished in state court. The petitioner in Case io has a state post-conviction proceeding pending.

In sum, of the eighteen cases granting relief, habeas was no help to the petitioner in at least four cases, eliminated the only basis for the petitioner's custody in at least four cases, and seems to have resulted in some reduction of the petitioner's term of incarceration in the rest.

If we assume that all but four of the petitioners who secured relief benefited from their habeas litigation, including the case still pending in state court, that is a total of fourteen cases in which federal habeas review actually benefited the petitioner, out of the $2 \mathrm{I} 88$ cases filed in 2003 and 2004 that a district court had completed by December 20II-an effective relief rate of 0.64 percent.

\section{Conclusion}

The 2007 study found that non-capital petitioners filing after AEDPA were even less likely than pre-AEDPA petitioners to win in the district courts. Now, seven to eight years after the study cases were filed, with time to see what happened to these cases after appeal, a more complete picture emerges. Even after appellate review, the number of non-capital petitioners receiving habeas relief remains less than the I percent rate reported prior to AEDPA.

The analysis also illustrates the mixed results that the tiny cohort of successful petitioners ultimately experiences. Assuming the random sample of cases in the 2007 study roughly reflects the distribution of cases nationwide, some of the petitioners who win in federal court will be released from state custody-at least one here was shown to be factually innocent-but for others a grant of federal habeas relief will make no difference. Most winning petitioners will secure, many years after their initial convictions, an opportunity to demand a second chance at trial, sentencing, or appeal. Depending upon the availability of evidence, the prospects for success, the likelihood that the petitioner will remain incarcerated anyway on other charges, and other factors, the state may choose to proceed with the new trial, sentencing, or appeal, abandon the charge, or simply negotiate a settlement to a lesser charge or sentence.

The policy suggestions that follow from the reality of federal habeas litigation under AEDPA will continue to be debated in this issue and elsewhere. Hopefully, the new information in this article will provide additional empirical grounding for that discussion.

\section{Notes}

1 This research was funded by the Vanderbilt University Law School. I am grateful for the assistance of the four talented Vanderbilt students who served as research assistantsRebecca Dunnan, Will Peeples, and David von Wiegant, who collected and coded this information with me, and Justin Tate, who followed these cases back into the state courts.

2 The 2007 study was a joint effort of the National Center for State Courts and Vanderbilt University Law School, with fund ing from the National Institute of Justice and assistance from an advisory board of defenders, states' attorneys, and state and federal judges. See Nancy J. King, Fred L. Cheesman II \& Brian J. Ostrom, Final TECHNICAL Report: Habeas Litigation IN U.S. District Courts: An Empirical Study of Habeas Corpus Cases Filed by State Prisoners Under the Antiterrorism and Effective DeAth PENAlty ACt of 1996, available at https://www.ncjrs.gov/ pdffiles1/nij/grants/219559.pdf [hereinafter 2007 STUDY].

Information for the 2007 study and this article was col. lected for 2384 randomly selected non-capital habeas cases filed in district courts across the country during 2003 and 2004 , about 6.5 percent of the total non-capital habeas cases filed in district courts during that period. See id. at 14-18 (discussing methodology). The study also examined 368 cases commenced by state death row prisoners between 2000 and 2002 in those districts with the highest volume of capital case filings. These capital cases are not covered in this article. The study's findings on non-capital cases are also discussed in Joseph L. Hoffmann \& Nancy J. King, Rethinking the Federal Role in State Criminal Justice, 89 N.Y.U. L. Rev. 791 (2009), and Nancy J. King \& Suzanna Sherry, Habeas Corpus and State Sentencing Reform: A Story of Unintended Consequences, 58 DUKE L.J. 1 (2008). Both capital and non-capital case findings from the study, as well as the writ's develop. ment over time and its use by federal prisoners and detainees, are discussed in NANCY J. KING \& JOSEPH L. HoffmANn, HABEAS For the TWENTY-FIRST CENTURY: USES, ABUSES, AND THE FUtURE OF THE GREAT WrIT (2011).

3 Court of appeals cases related to each district court case were identified by (1) searching for circuit case numbers on the district court docket sheet itself (available on PACER), (2) searching for circuit case numbers in documents available from PACER that were docketed in the district court case, (3) searching for appeals cases in the PACER website for each court of appeals using the district court docket number and petitioner name, and (4) checking the individual websites of each court of appeals, which sometimes provided search capabilities and access to various orders beyond those available in PACER. For cases in which no appellate activity was located with these techniques, I checked the Appellate Termination data sets from the Federal Court Cases: Integrated Data Base Series for cases listing the petitioner's name or listing the district court docket num ber as the originating case, but this added check produced no additional cases (for a significant proportion of cases in the data sets, this information was missing). By December 2011, when this coding was completed, only 12 of the 2384 study cases were still pending in the district courts.

4 See Tables B.7 and C.2 for each year's caseload statistics reported on the website of the Administrative Office of the Courts, www.uscourts.gov. In 2011, 6260 non-capital state habeas cases were filed in the courts of appeals compared to 16,673 of the same type of case filed in the district courts. Original coding of documents from PACER was undertaken for this study rather than relying on information collected in the AO's data sets, where much of the information required is missing.

5 The 2384 district court cases in the study sample produced 2188 dispositions. Most of the remaining 196 cases were 
transferred to another district; twelve remain pending in the district courts and have not reached final judgment.

6 Although these four categories of filings were not coded or tracked systematically, more than two percent of cases in the sample included one or more interlocutory or duplicate appeals. The count of appellate activity generated by the study cases also does not include remands by the courts of appeals for a district court ruling on a certificate of appealability (COA). See text at notes 10-14 infra. The Ninth Circuit, for example, regularly remanded cases to district courts for a ruling on a COA before proceeding-essentially considering the case twice.

The appellate decisions also generated a significant num. ber of motions for rehearing in the courts of appeals, as well as many petitions for writs of certiorari in the Supreme Court, but how many was not collected. One of the non-capi. tal cases in the study was reviewed by the Supreme Court, which affirmed the court of appeals' decision affirming the district court's dismissal: Day v. McDonough, 547 U.S. 198 (2006). Also not included in the count of appellate activity were requests for permission to file a successive petition that were not filed in the court of appeals immediately following the district court's dismissal on that basis. See infra note 16

7 The 2007 study reported that seven of the non-capital cases in the study sample had ended in grant by the time the Report went to press, with 8 percent of the sample still pend. ing. 2007 STUDY, supra note 2, at 7, 58 n.109. Four and a half years later, seven of those pending cases had produced a grant of relief in the district court. This higher rate of relief for extremely slow cases is consistent with the 2007 study's finding that capital cases in which relief was granted tended to take longer than other cases. Id. at 8 .

8 Of the 2174 petitioners who lost in the district court, 817 attempted to appeal their adverse judgments. Among cases in which the district court denied any claim on the merits, the appeal rate was somewhat higher-about half of these cases were appealed. As one might expect, the appeal rate was much lower for cases in which all claims were voluntarily dismissed, dismissed as unexhausted, or dismissed for mootness, lack of custody, or failure to pay the filing fee or comply with filing requirements. Some of the attrition in habeas litigation into the courts of appeals is probably explained by the release of some of these petitioners. A num. ber of district and appellate dockets (this was not specifically counted) indicated that the order denying relief was returned undeliverable from the petitioner's last known address, for example.

9 The Court of Appeals ordered some sort of remand in 16 of the 817 appeals by petitioners. In three cases, the appeal of the district court's denial or dismissal is still pending in the Ninth Circuit.

10 If the district court denies a COA, a petitioner can seek a COA from the court of appeals. Likewise, if the district court grants a COA on one issue, the petitioner can ask the court of appeals to enlarge the COA to permit review of additional issues. Certificates of appealability are not required if the state seeks to appeal, nor, in some circuits, if the prisoner is challenging a decision other than conviction or sentence. See King \& Sherry, supra note 2, at 46-47.

1128 U.S.C. § 2253; Miller-El v. Cockrell, 537 U.S. 322 (2003); Gonzalez v. Thaler, 132 S. Ct. 641 (2012).

12 Specifically, 48 percent; 1048 of 2174.

13 Of the fifty-five cases in which a COA was granted by the dis. trict court, three were not appealed.

14 This number includes some cases in which the court of appeals held a COA was not a prerequisite to appeal. See supra note 10 .

1528 U.S.C. § 2244(b)(2) (1996).
16 Whenever a petitioner filed two separate cases, one appealing the district court's decision and another seeking permission to file a successive petition, the appeal was coded but not the request for permission. Only those requests for permission filed within three months of the district court's dismissal were considered to be appellate activity generated by the dis trict court case; later requests were not examined, nor were requests that had been filed before the termination of the district court case.

17 In a number of cases the petitioner appealed the district court's dismissal of his petition as successive, and these appeals are counted as appeals, not requests to file a succes. sive petition. None of these appeals succeeded, either.

It is important to note that this study did not seek to determine how often prisoners ask the court of appeals for permission to file second or successive petitions, or how often those requests are granted. The analysis reported here attempts to measure only how often a prisoner is granted permission to file a new petition when he files his request immediately follow. ing dismissal of his case in the district court. The answer appears to be that such requests are rarely granted; none of the seventy-three requests made by petitioners in the study sample were granted. Also, neither this analysis nor the 2007 study tracked whether or not the initial filing in district court was preceded by an order from the court of appeals granting the petitioner's request to file a successive petition.

18 See 2007 STUDY, supra note 2, at 12.

19 See id. at 56 (noting studies of habeas litigation prior to AEDPA, finding that 1 percent of claims and 1 percent of petitioners received relief in the district courts).

Three Cornell researchers have reported a different set of statistics-concluding that "the set of successful noncapital cases grows by $22 \%$ when appellate out comes are considered." John H. Blume, Sheri Lynn Johnson \& Keir M. Weyble, In Defense of Noncapital Habeas: A Response to Hoffmann and King, 96 CORNELL L. REv. 435, 452 (2011). They based this conclusion on their evaluation of 1547 court of appeals decisions handed down between July 2005 and September 2009 in non-capital cases, but they do not state how these cases were identified or whether they consider the sam. ple to be a random or representative sample of court of appeals activity in non-capital habeas cases. Recall that over 6000 such cases are filed in the courts of appeals every year. Specifically, from 2005 to 2009, the period they evaluated, the Administrative Office reported that more than 25,000 such cases were filed in the courts of appeals. If the courts of appeals are terminating these cases at about the same rate that they are filed, the Cor nell team evaluated approximately 6.2 percent of all appellate decisions. They report, id. at note 91 :

In all, 1,547 noncapital court of appeals decisions in $\S 2254$ cases were reviewed. Of these, 630 dispositions on grounds other than an outright merits decision (e.g., denials of a certificate of appealability, dismissals for untimeliness, or remands following grants or denials of relief) were set aside. The result. ing set of 917 decisions involved cases in which a district court had either granted or denied relief on the merits, and the court of appeals either affirmed or reversed the district court's judgment on the merits without remanding the case for further proceedings (e.g., an evidentiary hearing, consideration of a procedural default issue, or consideration of a timeli. ness issue). Of the 126 district court grants of relief that were appealed, 60 were affirmed and 66 were reversed; of the 791 district court denials of relief, 697 were affirmed and 94 were reversed. 
The absolute size of the sample of appellate decisions evalu. ated by the Cornell researchers is larger than the sample evaluated here (1547 cases decided by the courts of appeals over four years, compared to 823 appeals filed from the random sample of two years' filings in district court), but without knowing more about how the particular decisions were selected from among the thousands of court of appeals cases litigated during the four-year period sampled by the Cornell researchers, it is impossible to evaluate their find. ings. Their findings, based on appeals decided, are in any event quite different than the findings reported here, which are based on a random sample of district court filings followed not just through the appellate decision stage but also through post-remand proceedings in federal and state court.

The Cornell researchers' "22\% increase" prediction reflects their conclusion that among the set of appellate decisions they evaluated, there were 126 cases that reviewed district court grants, compared to 154 cases of relief after appellate review (sixty grants that were affirmed combined with ninety-four denials that were reversed). Applying that change rate to all of the cases in the 2007 Study sample that were granted at the district court level (even those not appealed) results in a prediction of seventeen cases with relief, close to the eighteen actually pro. duced. The state win rate on appeal that the Cornell team reports, however, is much higher than the one found in the ran dom sample of cases in the 2007 study: 52 percent (Cornell sample) compared to 33 percent (random 2007 study sample).

Using their sample, the Cornell researchers also found varia. tions between circuits in the proportion of merits decisions finding for petitioners. Id. at note 92. As noted earlier, the per centage of cases accepted for appellate review through COAs varies significantly between circuits, so it would not be surpris. ing to find that once that selection is made, the rates of relief vary as well. For example, among the 2007 study cases, in the Ninth Circuit there were 461 completed, non-transferred cases decided against the petitioner in district court; fifty-two of those received a COA-thirty from the court of appeals — but only four were remanded, and only two of those four were granted relief in the district court on remand. Compare that to the Fifth Circuit, where only 7 of 415 cases decided against the petitioner received a COA-all seven from the court of appeals itself; five of those seven were remanded, with two of the five granted relief by the district court after remand. Given a similar number of district court decisions against petition. ers-415 and 461-appellate review of those decisions in these two circuits ultimately produced a similar number of cases with relief, just two, despite very different selection pat. terns for accessing and resolving appeals.

20 This number is the 2384 cases, minus those transferred to another district, and minus the twelve cases that had not been terminated as of December 2011 when coding for this study was closed.

21 See King \& Hoffmann, supra note 2, at ch. 9; King \& Sherry, supra note 2 .

22 At least one of the petitions from the study that was granted would probably be denied today. In Case 18, the Ninth Circuit remanded the case for an evidentiary hearing to develop new evidence, beyond the evidence considered by the state court, in order to determine if relief under $\S 2254$ (d) was warranted for the petitioner's McKaskle claim. This remand in turn led to a negotiated settlement of the habeas case with the petitioner pleading guilty to the same offense with a lesser sentence and withdrawing his habeas challenge. If litigated today, the Court's 2011 decision in Cullen v. Pinholster would probably lead the court of appeals to decline to remand for an evidentiary hearing in this situation.

Two additional Ninth Circuit decisions granting relief also appear to be undermined by the Court's 2011 decision in
Harrington v. Richter, which made it clear that relief under $\S 2254(d)$ is not available unless the state decision is "so lacking in justification that there was an error well under. stood and comprehended in existing law beyond any possibility for fairminded disagreement." In both decisions, the Ninth Circuit judges_presumably "fairminded"-dis. agreed over whether there was error. In one case, Case 11, the judges disagreed about whether the denial of a selfdefense instruction was error. See Lagunas v. Acting Warden ISP, No. CV 07.4852-DOC (JEM), 2010 WL 5343505 (C.D. Cal. Dec. 21, 2010) (acknowledging doubt about the position of the majority that the failure to instruct in this situation violates a clearly established Supreme Court rule). In the other case, Case 13, the appellate panel split on whether petitioner had shown prejudice from his lawyer's oversight-specifically, whether given the chance on appeal, petitioner could have established that instead of pleading guilty, he would have gone to trial had he been aware of the likely life sentence. Two judges decided he met that burden, relying on the peti. tioner's claims that he expected ten years if he pleaded guilty, while the dissenting judge pointed to petitioner's statements that he wanted to avoid a trial of the allegations of child sexual abuse in order to protect his son. See also Premo v. Moore, 131 S. Ct. 733, 745 (2011) (explaining why a defendant who enters a plea agreement carries a "substantial burden to show ineffective assistance of counsel," and must establish a "reasonable probability that, but for counsel's errors, he would not have pleaded guilty and would have insisted on going to trial").

Finally, the grant of relief in Case 14 was the result of a COA by the Tenth Circuit that was limited to the question whether the district court had jurisdiction to grant the Rule 59 motion; the COA did not identify the constitutional violation for which the defendant had made a substantial showing. Gonzalez v. Thaler, 132 S. Ct. 641 (2012), calls such a COA into question. See note 26 infra.

Though it is tempting to second-guess some of these grants under recent precedent, recent precedent may undermine an unknown number of denials and dismissals as well. Not all recent decisions of the Court have restricted relief. It is possible, for example, that some of the hundreds of petitioners in the study whose petitions were time barred might have succeeded in showing the extraordinary circumstances that the Court in 2010 recognized should warrant equitable tolling, and might have gone on to establish constitutional error. In other words, because decisions handed down since the study cases were resolved have cut both ways, one cannot be certain how those changes may have affected the effective rate of relief.

232007 STUDY, supra note 2, at 23.

24 Four were appointed counsel by the district court, and four had retained counsel. This analysis did not examine how common it was for counsel to be appointed in the particu. lar districts in which these cases were filed. As the 2007 study noted, appointing counsel was routine in at least one district when the study cases were filed in 2003 and 2004. Id. at 23 .

25 One had counsel appointed after briefing, before oral argu ment; one had retained counsel in the district court and appointed counsel for the appeal; and two had appointed counsel at both levels.

26 Interestingly, at least three of these cases involved a COA grant that, rather than identifying a constitutional violation for which petitioner had made a substantial showing, instead identified an issue of habeas procedure only. As Gonzalez v. Thaler, 132 S. Ct. 641 (2012), notes, every COA requires the petitioner to make "a substantial showing of the denial of a constitutional right" and must indicate which right that is. 